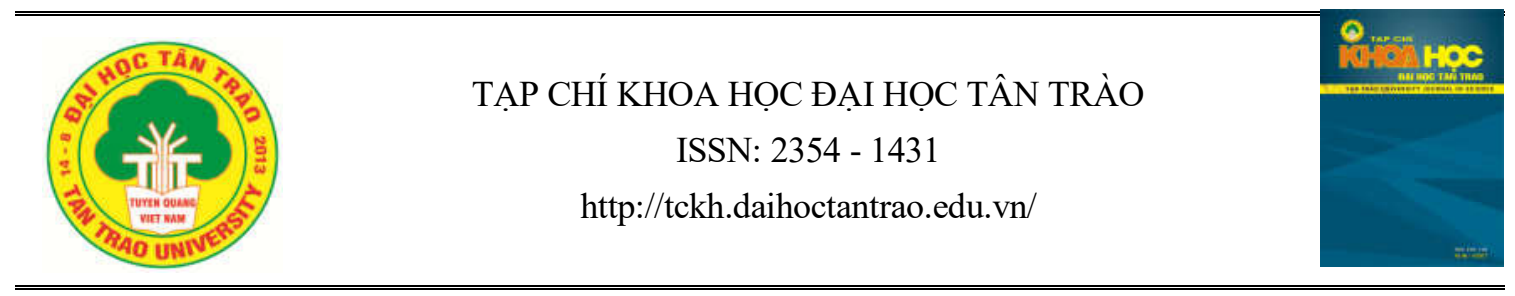

\title{
Nghiên cứu ảnh hưởng của con người đến tính đa dạng thực vật tại Khu di tích lịch sử Tân Trào, tỉnh Tuyên Quang
}

\author{
Đố Công $B a^{a^{*}}$ \\ ${ }^{a}$ Truò̀ng Đại học Tân Trào \\ *Email: congbacdsp@gmail.com
}

\section{Thông tin bài viết}

Ngày nhận bài:

10/01/2020

Ngày duyệt đăng:

$10 / 3 / 2020$

Tù khóa:

Khu di tich; khai thác;

đa dạng; Tân Trào;

tỉnh Tuyên Quang.

\section{Tóm tắt}

Kết quả nghiên cứu tại Khu di tích lịch sử Tân Trào, tỉnh Tuyên Quang đã cho thấy những hoạt động khai thác quá mức nguồn tài nguyên rừng ở đây đã làm suy giảm mạnh tính đa dạng của các nhóm loài thực vật rừng. Nhóm cây làm thuốc có 470 loài, trong đó 10 loài bị khai thác với tần suất lớn gồm Ba kích, Củ dòm, Hà thủ ô đỏ, Lá khôi, Tắc kè đá...; nhóm cây ăn được có 142 loài cũng thường xuyên bị thu hái, tận diệt như Rau sắng, Rau dớn, các loại quả Trám đen, Trám trắng, các loại măng như Vầu, Nứa, Giang; nhóm cây làm cảnh có 99 loài gồm Lộc vừng, Đa, Sanh, Trúc vuông...; nhóm cây cho tinh dầu có 69 loài, chiếm $9,5 \%$ tổng số loài thực vật đã điều tra được ở khu vực nghiên cứu. Một số loài thường gặp nhu: Hoa Giẻ Thơm (Desmos chinensis), Ké đầu ngựa (Xanthiuminae quilaterum), Màng tang (Litsea cubeba), Bồ hòn (Sapindus saponaria)..... Do việc khai thác quá mức trong thời gian dài trước đây của con người đến thành phần loài, cấu trúc phân tầng của rừng tự nhiên mà hiện nay ở Khu di tích có nhiều kiểu thảm thực vật khác nhau. Các kiểu thảm thực vật này có sự khác nhau rõ rệt giữa rừng tự nhiên được bảo vệ và rừng tái sinh bị khai thác kiệt.

\section{Mở đầu}

Khu di tích lịch sử Tân Trào, tỉnh Tuyên Quang cách thành phố Tuyên Quang khoảng $40 \mathrm{~km}$, cách thủ đô Hà Nội khoảng $150 \mathrm{~km}$ về phía Bắc. Khu di tích thuộc địa bàn 11 xã: Tân Trào, Minh Thanh, Trung Yên, Bình Yên, Lương Thiện (huyện Sơn Dương); Kim Quan, Trung Sơn, Hùng Lợi, Trung Minh, Đạo Viện, Công Đa (huyện Yên Sơn) với tổng diện tích tự nhiên là 48.035,27 ha. Nơi đây được biết đến với những cánh rừng già đại ngàn, đã che chở bảo vệ cho Chủ tịch Hồ Chí Minh, Trung ương Đảng, Chính phủ, Quốc hội, Mặt trận, các bộ, ban, ngành trung ương trong thời kỳ chuẩn bị Tổng khởi nghĩa giành chính quyền Tháng Tám năm 1945 và trong cuộc kháng chiến chống thực dân Pháp xâm lược [1]. Đến nay chưa có công trình nào công bố về các yếu tố ảnh hưởng đến tính đa dạng thảm thực vật rừng ở đây. Vì vậy, nội dung bài báo này trình bày kết quả nghiên cứu về các yếu tố ảnh hưởng của con người đến tính đa dạng của hệ thực vật và thảm thực vật rừng tự nhiên ở Khu di tích lịch sử Tân Trào, nhằm góp phần phục vụ công tác quản lý, bảo vệ và phát triển bền vững Khu di tích lịch sử Quốc gia đặc biệt này.

\section{2. Đối tượng, phương pháp nghiên cứu}

\section{1 Đối tượng}

Đối tượng nghiên cứu là ảnh hưởng của con người đến tính đa dạng thực vật tại Khu di tích lịch sử Tân Trào, tỉnh Tuyên Quang. Thời gian nghiên cứu từ tháng 6 năm 2016 đến tháng 3 năm 2018.

- Điều tra thực địa được tiến hành từ năm 2016 đến năm 2017, cụ thể: Đợt 1: tháng 6/2016; Đợt 2: tháng 9/2016; Đợt 3: tháng 12/2016; Đợt 4: tháng 3/2017. 
- Thực hiện điều tra phỏng vấn đợt 1: tháng 8/2016, đợt 2: tháng 10/2016, đợt 3: tháng 12/2016.

\subsection{Phưong pháp nghiên cúu}

2.2.1. Phương pháp thu mẫu và xủ lý mẫu thực vật

Điều tra, thu thập mẫu thực vật theo tuyến và ô tiêu chuẩn, xử lý mẫu theo các tài liệu của Hoàng Chung (2008) [3], Nguyễn Nghĩa Thìn (2007) [4].

\subsubsection{Phương pháp định loại mẫu thục vật}

Sử dụng phương pháp so sánh hình thái và dựa vào các tài liệu của Nguyễn Tiến Bân (2003-2005) [5], Phạm Hoàng Hộ (1993) [6]. Lập danh lục thực vật theo Brummitt (1992) [8]. Xác định dạng sống thực vật theo Raunkiaer (1934) [9]. Đánh giá về giá trị sử dụng của các loài thực vật theo các tài liệu của Võ Văn Chi (2012) [10], Trần Đình Lý (1993) [11], Triệu Văn Hùng (2007) [12].

2.2.3. Phuoong pháp đánh giá nhanh nông thôn có sụ tham gia của người dân (PRA)

Thực hiện phỏng vấn thông qua phiếu phỏng vấn với 100 hộ dân ở 11 xã thuộc khu di tích lịch sử Tân Trào. Mỗi xã phỏng vấn một nhóm từ 8-10 người dân đại diện cho các hộ gia đình có hoạt động khai thác và sản xuất lâm nghiệp.

\section{Kết quả nghiên cứu}

\subsection{Anh hương của con ngưòi đến nhóm loài thục vật}

\subsubsection{Hoạt động khai thác gố}

Qua điều tra xác định được 188 loài cây lấy gỗ (chiếm $25,9 \%$ ), hiện nay các loài cây gỗ quý có đường kính lớn như: Đinh, Lim, Sến, Táu...còn lại rất ít, chủ yếu còn tồn tại ở xung quanh các điểm di tích hoặc mọc rải rác trong các khu rừng tự nhiên được bảo vệ nghiêm ngặt. Số liệu ở Bảng 1 , chúng tôi đã tiến hành phỏng vấn 344 người thuộc 11 xã khu vực nghiên cứu, kết quả ghi nhận giai đoạn từ năm 2000 - 2010 có 253 người (chiếm 73,55\%) có hoạt động khai thác gỗ. Giai đoạn từ năm 2010 - 2018 có 175 người (chiếm 50,87\%) có khai thác gỗ, trung bình cả giai đoạn từ năm 2000 - 2018 có $62,2 \%$ tham gia hoạt động khai thác gỗ. Từ sau năm 2010 số người khai thác gỗ đã giảm $(22,68 \%)$, nguyên nhân là do các cơ quan chức năng đã bảo vệ rừng nghiêm ngặt hơn, mặt khác trữ lượng gỗ của rừng tự nhiên đã giảm đi rất nhiều, những cây gỗ quí đường kính lớn từ $1,5-2 \mathrm{~m}$ hầu như rất ít gặp, chỉ còn lại những cây gỗ nhỏ.

Bảng 1. Thống kê các loài cây gố thuờng bị khai thác tại Khu di tích lịch sủ Tân Trào

\begin{tabular}{|c|c|c|c|c|c|c|c|}
\hline \multirow[b]{2}{*}{ TT } & \multicolumn{2}{|l|}{ Tên loài } & \multirow[b]{2}{*}{$\begin{array}{c}\text { Số người } \\
\text { phợng } \\
\text { vấn }\end{array}$} & \multicolumn{2}{|c|}{$\begin{array}{c}\text { Thò̀ gian } \\
2000-2010\end{array}$} & \multicolumn{2}{|c|}{$\begin{array}{c}\text { Thời gian } \\
2010-2018\end{array}$} \\
\hline & Tên Khoa học & $\begin{array}{c}\text { Tên } \\
\text { Việt Nam }\end{array}$ & & $\begin{array}{c}\text { Số } \\
\text { người } \\
\text { khai } \\
\text { thác }\end{array}$ & $\begin{array}{l}\text { Tỷ lệt } \\
\text { (\%) }\end{array}$ & $\begin{array}{c}\text { Số } \\
\text { người } \\
\text { khai } \\
\text { thác }\end{array}$ & $\begin{array}{l}\text { Tŷ̀ lệ } \\
(\%)\end{array}$ \\
\hline 1 & Markhamia stipulata & Đinh & 45 & 40 & 88,89 & 32 & 71,11 \\
\hline 2 & Peltophorum tonkinensis & Lim xẹt & 42 & 26 & 61,90 & 18 & 42,86 \\
\hline 3 & Melia azedarach & Xoan ta & 38 & 32 & 84,21 & 28 & 73,68 \\
\hline 4 & Madhuca pasquieri & Sển mật & 50 & 33 & 66,00 & 21 & 42,00 \\
\hline 5 & Michelia balansae & Giổi lông & 52 & 36 & 69,23 & 17 & 32,69 \\
\hline 6 & Canarium album & Trám trắng & 41 & 33 & 80,49 & 25 & 60,98 \\
\hline 7 & Chukrasia tabu & Lát ho & 36 & 24 & 66,67 & 19 & 52,78 \\
\hline 8 & Vatica ordorata & Táu lá nhỏ & 40 & 29 & 72,50 & 15 & 37,50 \\
\hline & Tổng & & 344 & 253 & 73,55 & 175 & 50,87 \\
\hline
\end{tabular}

(Nguồn: Số liệu điều tra của tác giả)

Khi điều tra chúng tôi nhận thấy trước đây mục đích của người dân khai thác gỗ chủ yếu để làm nhà, đóng đồ dùng trong gia đình, làm chuồng trại cho gia cầm, gia súc. Nhưng ngày nay mục đích khai thác gỗ còn để bán tăng thêm thu nhập cho gia đình. Chúng tôi tiến hành nghiên cứu 11 xã tại Khu di tích lịch sử Tân Trào chọn mỗi xã chọn 10 người và phỏng vấn bằng phiếu điều tra những người có liên quan đến hoạt động khai thác gỗ, kết quả tổng hợp ở Bảng 2. Như vậy, số người khai thác gỗ để bán theo các mốc thời gian khác nhau đều cao hơn số người khai thác gỗ để sử dụng trong gia đình.

Bảng 2. Thống kê mục đích khai thác gỗ tù năm 1990 - 2018 tại Khu di tích lịch sử Tân Trào

\begin{tabular}{|c|c|c|c|c|c|c|}
\hline \multirow{3}{*}{ Thò̀i gian } & \multicolumn{4}{|c|}{ Mục đích khai thác gỗ } & \multirow{2}{*}{\multicolumn{2}{|c|}{ Tỗng }} \\
\hline & \multicolumn{2}{|c|}{ Để sử dụng } & \multicolumn{2}{|c|}{ Để bán } & & \\
\hline & $\begin{array}{l}\text { Số ngưò̀i } \\
\text { khai thác }\end{array}$ & $\begin{array}{l}\text { Tỷ lệ } \\
(\%)\end{array}$ & $\begin{array}{l}\text { Số người } \\
\text { khai thác }\end{array}$ & $\begin{array}{l}\text { Tỷ lệ } \\
(\%)\end{array}$ & $\begin{array}{l}\text { Số người } \\
\text { điều tra }\end{array}$ & $\begin{array}{l}\text { Tỷ lệ } \\
(\%)\end{array}$ \\
\hline $1990-2000$ & 75 & 68,2 & 82 & 74,5 & 110 & 100,0 \\
\hline $2000-2010$ & 42 & 38,2 & 79 & 71,8 & 110 & 100,0 \\
\hline $2010-2018$ & 34 & 30,9 & 76 & 69,1 & 110 & 100,0 \\
\hline
\end{tabular}

(Nguồn: Số liệu điều tra của tác giả)

Do khai thác, buôn bán gỗ bất hợp pháp đem lại thu nhập cao, nhiều người dân đã bỏ ruộng vườn để vào rừng khai thác gỗ. Số liệu ở bảng 3 cho thấy, trong giai đoạn từ năm 2013 - 2017 tại Khu di tích lịch sử Tân Trào tổng số vụ vi phạm luật bảo vệ và phát triển rừng bị cơ quan chức năng xử lý là 677 vụ, trong đó vi phạm trực tiếp liên quan đến rừng là 179 vụ (chiếm 26,44\%), vi phạm gián tiếp là 498 vụ (chiếm 73,56\%). Thống kê cũng chỉ ra trong 5 năm các vụ vi phạm như phá rừng trái phép, khai thác gỗ trái phép là 108 vụ (chiếm 60,33\% số vụ vi phạm trực tiếp liên quan đến rừng). 
Bảng 3. Thống kê các vụ vi phạm luật bảo vệ và phát triển rùng tại Khu di tích lịch sủ Tân Trào tù̀ năm 2013-2017

\begin{tabular}{|c|c|c|c|c|c|c|c|}
\hline \multirow{2}{*}{ TT } & \multirow{2}{*}{ Tên vụ vi phạm } & \multicolumn{5}{|c|}{ Năm } & \multirow{2}{*}{ Tổng } \\
\hline & & 2013 & 2014 & 2015 & 2016 & 2017 & \\
\hline \multicolumn{7}{|c|}{ Vi phạm trục tiếp } & 179 \\
\hline 1 & Quy định về bào vệ rừng & 15 & 10 & 3 & 0 & 0 & 28 \\
\hline 2 & $\begin{array}{l}\text { Chẳn thà gia súc trong khu rừng } \\
\text { cấm }\end{array}$ & 2 & 0 & 0 & 0 & 0 & 2 \\
\hline 3 & $\begin{array}{l}\begin{array}{l}\text { Quy định về PCCCR gây cháy } \\
\text { rừng }\end{array} \\
\end{array}$ & 0 & 0 & 3 & 4 & 0 & 7 \\
\hline 4 & Phá rừng trái phép & 33 & 40 & 1 & 4 & 7 & 85 \\
\hline 5 & Khai thác gỗ trái phép & 4 & 5 & 3 & 6 & 5 & 23 \\
\hline 6 & $\begin{array}{l}\text { Thủ tục trong quàn lý, sử dụng } \\
\text { rừng }\end{array}$ & 0 & 1 & 4 & 4 & 6 & 15 \\
\hline 7 & Thù tục trong khai thác rừng & 0 & 2 & 5 & 6 & 6 & 19 \\
\hline \multicolumn{7}{|c|}{ Vi phạm gián tiếp } & 498 \\
\hline 8 & Vận chuyển lâm sản trái phép & 15 & 19 & 15 & 3 & 17 & 69 \\
\hline 9 & Cất giữ lâm sản trái pháp luật & 5 & 6 & 8 & 9 & 10 & 38 \\
\hline 10 & $\begin{array}{l}\text { Chế biến, kinh doanh lâm sản } \\
\text { trái phép }\end{array}$ & 0 & 0 & 0 & 0 & 2 & 2 \\
\hline 11 & $\begin{array}{l}\text { Thủ tục trong vận chuyền lâm } \\
\text { sản }\end{array}$ & 32 & 41 & 45 & 7 & 12 & 137 \\
\hline 12 & Thủ tục trong mua bán lâm sản & 0 & 0 & 0 & 0 & 1 & 1 \\
\hline 13 & Thù tục trong cất giừ lâm sàn & 6 & 4 & 2 & 0 & 2 & 14 \\
\hline 14 & Thủ tục trong chể biến lâm sản & 6 & 3 & 9 & 19 & 1 & 38 \\
\hline 15 & Quy định hành chính khác & 68 & 48 & 38 & 29 & 16 & 199 \\
\hline \multicolumn{2}{|c|}{ Tỗng số vụ vi phạm } & 186 & 179 & 136 & 91 & 85 & 677 \\
\hline
\end{tabular}

Bảng 4. Thống kê các vụ vi phạm bị kiểm lâm bắt giũ tại 5 xã Khu di tích lịch sủ Tân Trào

\begin{tabular}{|c|c|c|c|c|c|}
\hline TT & Hành vi vi phạm & $\begin{array}{c}\text { Số vu } \\
\text { vi } \\
\text { phạm }\end{array}$ & Tang vật tịch thu & $\begin{array}{l}\text { Phurơng tiện tịch } \\
\text { thü }\end{array}$ & $\begin{array}{c}\text { Tổng tiền } \\
\text { phat (đấng })\end{array}$ \\
\hline \multicolumn{6}{|c|}{ Năm 2014 (50 vụ) } \\
\hline 1 & Khai thác rừng trái phép & 1 & \multirow{6}{*}{$\begin{array}{c}\text { Gỗ tron: } 0,898 \\
\mathrm{~m}^{3}, \\
\text { Gô̄ xè: } 4,177 \mathrm{~m}^{3} ; \\
\text { Lầm sàn ngàai gỗ: } \\
11 \text { kg; Động vật } \\
\text { rừng tịch thu: } 33 \\
\text { cà thế. }\end{array}$} & \multirow{6}{*}{$\begin{array}{l}\text { Xe mô tô, xe gấn } \\
\text { máy: } 00 \text { chî́ć; } \\
\text { Máy móc các laại: } \\
\text { 01chiếc; Công cụ } \\
\text { thú công: } 11 \\
\text { chiếc. }\end{array}$} & \multirow{6}{*}{35.400 .000} \\
\hline 2 & Phá nừng trái pháp luật & 2 & & & \\
\hline 3 & Vận chuyển lâm sản trái pháp luật & 1 & & & \\
\hline 4 & Vi phạmn thủ tục hành chính & 15 & & & \\
\hline 5 & $\begin{array}{l}\text { Vi pham các quy định chung của } \\
\text { nhà nước vể bào vệ rừng. }\end{array}$ & 10 & & & \\
\hline 6 & Hành vi vi phạm khác & 21 & & & \\
\hline \multicolumn{6}{|c|}{ Năm 2015 (33 vụ) } \\
\hline 1 & $\begin{array}{l}\text { Vi phạm các quy định chung của } \\
\text { nhà nước vế bảo vệ rừng. }\end{array}$ & 3 & \multirow{5}{*}{ 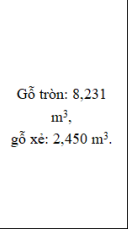 } & \multirow{5}{*}{$\begin{array}{l}\text { Xe mô tô, xe gắn } \\
\text { máy: } 05 \text { chiếc; } \\
\text { Công cụ thù công: } \\
05 \text { chiếc. }\end{array}$} & \multirow{5}{*}{29.875 .000} \\
\hline 2 & Vận chuyển lâm sản trái pháp luật & 1 & & & \\
\hline 3 & $\begin{array}{l}\text { Mua, bán, cất giứ, chể biến, kinh } \\
\text { coanh lâm sân trái với các quy } \\
\text { dịnh của nhà nước }\end{array}$ & 2 & & & \\
\hline 4 & Vi phạm thủ tục hành chính & 15 & & & \\
\hline 5 & Hành vi vi phạm khác & 12 & & & \\
\hline \multicolumn{6}{|c|}{ Năm $2016(20$ vạ) } \\
\hline 1 & Khai thác rừng trái phép & 1 & \multirow{6}{*}{ 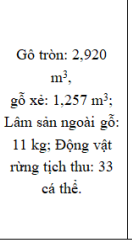 } & \multirow{6}{*}{$\begin{array}{c}\text { Xe môt tô, xe gắn } \\
\text { máy: } 04 \text { chiêce. } \\
\text { Máy móc các loại: } \\
02 \text { chiếc. } \\
\text { Công cụ thu công: } \\
03 \text { chiếc. }\end{array}$} & \multirow{6}{*}{50.500 .000} \\
\hline 2 & Phá rừng trải pháp luật & 2 & & & \\
\hline 3 & Vận chuyền lâm sản trái pháp & 1 & & & \\
\hline 4 & $\begin{array}{l}\text { Mua, bán, cát geiữ, chế biến, kinh } \\
\text { doanhl lâm sàn trái vói các quy } \\
\text { địnlh của nhà nước }\end{array}$ & 2 & & & \\
\hline 5 & Vi phạm thủ tục hành chính & 8 & & & \\
\hline 6 & Hành vi vi phạm thác & 6 & & & \\
\hline \multicolumn{6}{|c|}{ Năm 2017 (26 vụ) } \\
\hline 1 & Khai thác rừng trái phép & 3 & \multirow{6}{*}{$\begin{array}{c}\text { Gỗ tròn: } 2,043 \\
\mathrm{~m}^{3}(q u y, \text { hiềm } \\
\left.0,180 \mathrm{~m}^{3}\right) \text { gố xè: } \\
1,486 \mathrm{~m}^{3}\end{array}$} & \multirow{6}{*}{$\begin{array}{c}\text { Xe ôtô, máy kéo: } \\
01 \text { chiếc; Xe mố } \\
\text { tô, xe aắn máy: } 03 \\
\text { chiếc; Máy móc } \\
\text { các loại: } 03 \text { chiếc; } \\
\text { Công cut thu công: } \\
02 \text { chiếc. }\end{array}$} & \multirow{6}{*}{46.400 .000} \\
\hline 2 & Phá rừng trái pháp luật & 2 & & & \\
\hline 3 & Vận chuyển lầm sản trái pháp & 2 & & & \\
\hline 4 & 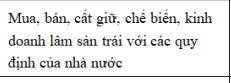 & 5 & & & \\
\hline 5 & Vi phạm thù tuc hành chinh & 8 & & & \\
\hline 6 & Hành vi vi phạm thác & 6 & & & \\
\hline
\end{tabular}

\begin{tabular}{|c|c|c|c|c|c|}
\hline & $2018(20 \mathrm{vu})$ & & & & \\
\hline 1 & Khai thác rừng trái phép & 2 & \multirow{6}{*}{ 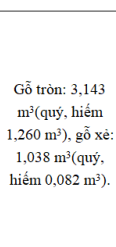 } & \multirow{6}{*}{$\begin{array}{l}\text { Xe mô tô, xe gấn } \\
\text { máy: } 02 \text { chiếc; } \\
\text { Công cu thú công: } \\
02 \text { chiếc }\end{array}$} & \multirow{6}{*}{20.850 .000} \\
\hline 2 & Phá rưng trái pháp luật & 1 & & & \\
\hline 3 & Vận chuyè̀n lâm sản trái pháp & 2 & & & \\
\hline 4 & $\begin{array}{l}\text { Mua, bán, cất giữ, chế biến, kinh } \\
\text { doanh lâm sån trái với các quy } \\
\text { định cua nhà nườc }\end{array}$ & 1 & & & \\
\hline 5 & Vi phạm thủ tục hành chính & 6 & & & \\
\hline 6 & Hành vi vi phạm khác & 8 & & & \\
\hline
\end{tabular}

(Nguồn: Hạt Kiểm lâm Khu di tích lịch sủ Tân Trào)
Để làm rõ hơn tình hình khai thác gỗ trái phép hiện nay, chúng tôi đã tiến hành thống kê các vụ vi phạm Luật bảo vệ và phát triển rừng tại 5 xã điển hình của Khu di tích lịch sử Tân Trào. Kết quả được thể hiện ở Bảng 4, trong 5 năm đã có 149 vụ vi phạm bị kiểm lâm bắt giữ, trong đó có 14 vụ vi phạm về phá rừng trái phép và khai thác rừng trái phép. Ngoài ra còn có thể có nhiều vụ vi phạm liên quan đến rừng nhưng không bị kiểm lâm phát hiện.

Bảng 4 cho thấy, số vụ vi phạm luật Bảo vệ và phát triển rừng ở 5 xã điển hình của Khu di tích lịch sử Tân Trào có xu hướng giảm. Cụ thể: năm 2013 có số vụ vi phạm nhiều nhất (50 vụ), số vụ vi phạm ít nhất là năm 2015 và 2017 (20 vụ). Tổng số gỗ khai thác trái phép bị tịch thu là $27,643 \mathrm{~m}^{3}$, tổng số tiền phạt là 183,025 triệu đồng. Tuy số lượng gỗ và số tiền bị phạt không lớn nhưng hoạt động khai thác gỗ trái phép, phá rừng trái phép vẫn diễn ra, hậu quả là đã làm suy giảm nguồn tài nguyên cây gỗ và ảnh hưởng đến sự tồn tại của nhiều loài thực vật và sinh vật khác trong cùng sinh cảnh sống. Vì vậy, các ban ngành chức năng của địa phương cần thực hiện các biện pháp hữu hiệu để giải quyết tình trạng này.

Hoạt động khai thác gỗ đã và đang là một vấn đề hết sức phức tạp, làm suy giảm nguồn tài nguyên cây gỗ và ảnh hưởng đến nhiều loài thực vật khác trong cùng sinh cảnh sống. Khi nhiều cây gỗ lớn bị chặt hạ sẽ tác động đến các loài khác do các nhân tố sinh thái (ánh sáng, độ ẩm, nhiệt độ...) thay đổi theo, ảnh hưởng tiêu cực đến tính đa dạng của hệ thực vật ở Khu di tích lịch sử Tân Trào.

\subsubsection{Hoạt động khai thác cây làm thuốc}

Qua điều tra chúng tôi nhận thấy trong số 470 loài cây làm thuốc (chiếm 64,74\%), có 10 loài người dân thường xuyên khai thác, các loài này hầu hết nằm trong danh mục các loài cây cần được bảo tồn. Từ kết quả điều tra trong Bảng 5 cho thấy bộ phận cây làm thuốc chủ yếu là thân cây, rễ cây, hoặc cả cây, nên khả năng tái sinh, sinh trưởng và phát triển của cây sẽ bị ảnh hưởng rất lớn, thậm chí nhiều loài có nguy cơ mất hẳn. 
Bảng 5. Danh sách các loài cây người dân thuờng khai thác làm thuốc tại Khu di tích lịch sủ Tân Trào

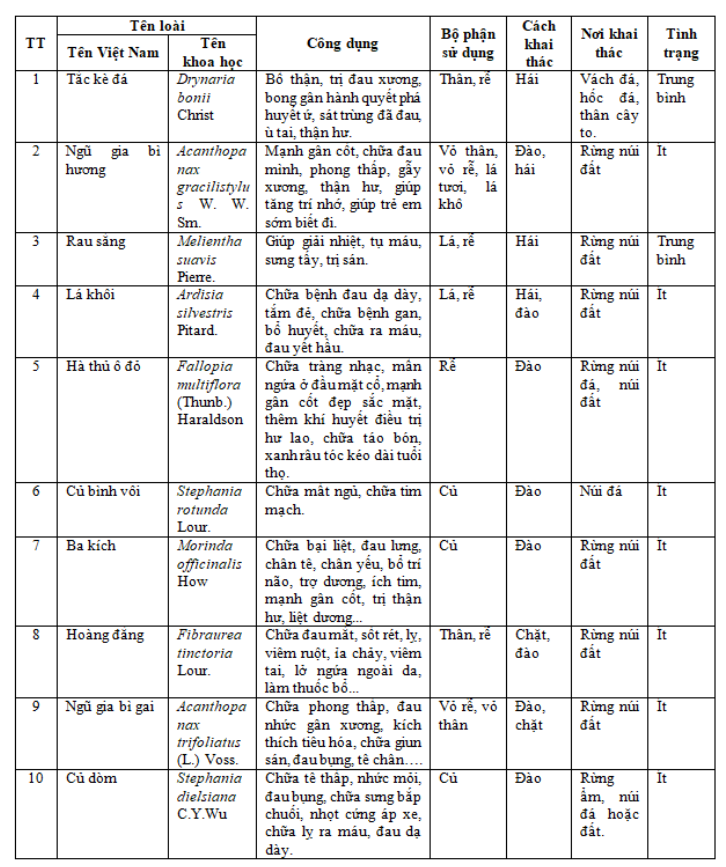

(Nguồn: Số liệu điều tra của tác giả)

Hiện nay, việc khai thác các loài cây thuốc tuy đã giảm so với trước đây, do sự giám sát của chính quyền các cấp, nhưng đây vẫn là hoạt động thường xuyên của đa số người dân địa phương, là sinh kế góp phần xóa đói giảm nghèo của người dân. Bảng 6 cho thấy khối lượng (tươi) ước tính một số loài cây thuốc khai thác tại khu vực nghiên cứu. Với việc khai thác như hiện nay, trong tương lai không xa, thảm thực vật rừng cũng sẽ bị suy giảm nghiêm trọng cả về diện tích và chất lượng rừng.

Bảng 6. Tình hình khai thác các loài cây làm thuốc tại Khu di tích lịch sủ Tân Trào

\begin{tabular}{|c|c|c|c|c|}
\hline \multirow[b]{2}{*}{ TT } & \multicolumn{2}{|r|}{ Tên loài } & \multirow[b]{2}{*}{$\begin{array}{l}\text { Khai thác } \\
\text { hàng năm }\end{array}$} & \multirow[b]{2}{*}{ Nơi tiêu thụ } \\
\hline & $\begin{array}{l}\text { Tèn Việt } \\
\text { Nam }\end{array}$ & Tên Khoa học & & \\
\hline 1 & Tắc kè đá & Diynaria bonii Christ & Dưới 1 tấn & $\begin{array}{l}\text { Tuyên Quang, Hà } \\
\text { Nội }\end{array}$ \\
\hline 2 & $\begin{array}{l}\text { Ngũ gia bì } \\
\text { hương }\end{array}$ & $\begin{array}{l}\text { Acanthopanax gracilistylus W. } \\
\text { W. Sm. }\end{array}$ & Dưới 1 tấn & $\begin{array}{l}\text { Tuyên Quang, Hà } \\
\text { Nội, Hài Phòng }\end{array}$ \\
\hline 3 & Rau sắng & Melientha suavis Pierre. & Trên 5 tấn & $\begin{array}{l}\text { Tuyên Quang, Hà } \\
\text { Nội, Thái Nguyên }\end{array}$ \\
\hline 4 & Lá khôi & Ardisia silvestris Pitard. & Từ 1 đến 5 tấn & $\begin{array}{l}\text { Tuyên Quang, } \\
\text { Thái Nguyên }\end{array}$ \\
\hline 5 & Hà thủ ô đỏ & $\begin{array}{l}\text { Fallopia multiflora (Thunb.) } \\
\text { Haraldson }\end{array}$ & Trên 5 tấn & $\begin{array}{l}\text { Tuyên Quang, Hà } \\
\text { Nội, Trung Quồc }\end{array}$ \\
\hline 6 & Củ bình vôi & Stephania rotunda Lour. & Dưới 1 tấn & $\begin{array}{l}\text { Tuyên Quang, } \\
\text { Trung Quồc }\end{array}$ \\
\hline 7 & Ba kich & Morinda officinalis How & Trên 5 tấn & $\begin{array}{l}\text { Tuyên Quang, Hà } \\
\text { Nội, Hòa Binh }\end{array}$ \\
\hline 8 & Hoàng đằng & Fibraurea tinctoria Lour. & Từ 1 đến 5 tấn & $\begin{array}{l}\text { Tuyên Quang, } \\
\text { Thái Nguyên }\end{array}$ \\
\hline 9 & Ngũ gia bì gai & $\begin{array}{l}\text { Acanthopanax trifoliatus (L.) } \\
\text { Voss. }\end{array}$ & Từ 1 đến 5 tấn & $\begin{array}{l}\text { Tuyên Quang, Hà } \\
\text { Nội }\end{array}$ \\
\hline 10 & Củ dòm & Stephania dielsiana C.Y.Wu & Từ 1 đến 5 tấn & $\begin{array}{l}\text { Tuyên Quang, Hà } \\
\text { Nội, Hà Nam }\end{array}$ \\
\hline
\end{tabular}

(Nguồn: Số liệu điều tra của tác giả)

\subsubsection{Hoạt động khai thác cây cho tinh dầu}

Điều tra khu vực nghiên cứu cho thấy có 69 loài cây cho tinh dầu (chiếm 9,50\%). Ở các địa phương thuộc Khu di tích việc sử dụng và khai thác nguồn tài nguyên này chưa nhiều. Tuy nhiên, Ban quản lý Khu di tích cần phải có kế hoạch bảo vệ vì những loài này có nguy cơ bị khai thác cạn kiệt rất cao khi nhu cầu của thị trường tăng cao trong tương lai. Bảng 7 là các loài cây có tinh dầu thường gặp tại Khu di tích.

Bảng 7. Danh sách các loài cây cho tinh dầu thuờng gặp tại Khu di tích lịch sủ Tân Trào

\begin{tabular}{|c|l|l|}
\hline TT & \multicolumn{1}{|c|}{ Tên khoa học } & Tên Việt Nam \\
\hline 1 & Litsea rotundifolia Hemsl. & Bời lời lá tròn \\
\hline 2 & Litsea verticillata Hance. & Bời lời lá vòng \\
\hline 3 & Acronychia pedunculata (L.) Miq. & Bười bung \\
\hline 4 & Pluchea indica (L.) Lees. & Cúc tần \\
\hline 5 & Ageratum conyzoides L. & Cứt lợn \\
\hline 6 & Blumea balsamifea (L.) DC. & Đại bi \\
\hline 7 & Cinnamomum balansae Lecomte & Gù hương \\
\hline 8 & Saururus chinensis (Lour.) Hort.ex Loud. & Hàm ếch \\
\hline 9 & Desmos chinensis Lour. & Hoa Giè Thơm \\
\hline 10 & Agastache rugosa (Fisch.et May.) Kuntze & Hoắc hương núi \\
\hline 11 & Piper lolot C.DC. & Lá lốt \\
\hline 12 & Litsea cubeba (Lour.) Pers. & Màng tang \\
\hline 13 & Artemisia vulgaris L. & Ngài cứu \\
\hline 14 & Acanthopanax trifoliatus (L.) Voss. & Ngũ gia bì gai \\
\hline 15 & Acrocephalus indicus (Burm.f.) Kuntze & Nhân trần \\
\hline 16 & Amomum villosum Lour. & Sa nhân \\
\hline 17 & Liquidambar formosana Hance. & Sau sau \\
\hline 18 & Phoebe lanceolata Nees. & Sụ cụt \\
\hline 19 & Homalomena occulta (Lour.) Schott. & Thiên niên kiện \\
\hline 20 & Pinus kesyia Royle ex Gordon. & Thông ba lá \\
\hline 21 & Xanthoxylum nitidum (Roxb.) DC. & Xuyên tiêu \\
\hline
\end{tabular}

(Nguồn: Số liệu điều tra của tác giả)

\subsubsection{Hoạt động khai thác cây ăn được}

Trong Khu di tích đã thống kê được 142 loài cây (chiếm 19,56\%) có giá trị sử dụng làm thức ăn (rau, củ, quả...) cho con người. Trong Bảng 8 chúng tôi chỉ trình bày 29 loài mà người dân thường khai thác nhiều như: Rau sắng (Meliantha suavis), Rau dớn (Callipteris esculenta), Rau dệu (Alternanthera sessilis), Rau khúc nếp (Gnaphalium polycaulon), Sấu (Dracontomelum duperreanum), Tai chua (Garcinia cowa), Trám đen (Canarium tramdenum), Trám trắng (C. album), Dọc (Garcinia multiflora)...; Một số loại măng như Nứa (Neohouzeana dullosa), Vầu (Bambusa nutans)...

Nhóm cây này có ý nghĩa hết sức quan trọng đối với đời sống của đồng bào dân tộc thiểu số, vì chúng là nguồn cung cấp thức ăn hàng ngày, được bà con khai thác thường xuyên dưới nhiều hình thức khác nhau. Đó cũng là một trong những nguyên nhân làm suy giảm nghiêm trọng đến đa dạng loài của thảm thực vật trong Khu di tích. 
Bảng 8. Các loài cây ăn được người dân thường xuyên khai thác tại Khu di tích lịch sủ Tân Trào

\begin{tabular}{|c|c|c|c|c|c|c|}
\hline 11 & $\begin{array}{l}\text { Neohouzeana dullosa } \\
\text { A. Camus }\end{array}$ & Núa & Măng & Ăn, bán & Đào & Tháng 8-11 \\
\hline 12 & $\begin{array}{c}\text { Oroxylon indicum (L.) } \\
\text { Vent. }\end{array}$ & Núc nác & $\begin{array}{l}\text { Lá, hoa, } \\
\text { quà non }\end{array}$ & Ăn & Hái & Mùa hè \\
\hline 13 & $\begin{array}{l}\text { Alternanthera sessilis } \\
\text { (L.) A. DC. }\end{array}$ & Rau dệu & Lá, thân & $\begin{array}{l}\text { Ăn, chăn } \\
\text { nuôi }\end{array}$ & Hái & $\begin{array}{c}\text { Tháng 10-2 } \\
\text { năm saut }\end{array}$ \\
\hline 14 & $\begin{array}{l}\text { Callipteris esculenta } \\
\text { (Retz.) J. Smith. }\end{array}$ & Rau dớn & $\begin{array}{l}\text { Lá, ngọn } \\
\text { non }\end{array}$ & Ăn, bán & Hái & $\begin{array}{c}\text { Mùa xuân, } \\
\text { tháng } 4,9 \text {, } \\
10\end{array}$ \\
\hline 15 & \begin{tabular}{|c|} 
Gnaphalium polycaulon \\
Pers. \\
\end{tabular} & $\begin{array}{l}\text { Rau khúc } \\
\text { nếp }\end{array}$ & Lá, thân & Ăn, bán & Hái & Mùa xuân \\
\hline 16 & $\begin{array}{c}\text { Gnaphalium leuteo- } \\
\text { album } \mathrm{L} \text {. }\end{array}$ & $\begin{array}{c}\text { Raul khúc } \\
\text { tè }\end{array}$ & Lá, thân & Ăn, bán & Hái & Mùa xuân \\
\hline 17 & $\begin{array}{l}\text { Centella asiatica (L.) } \\
\text { Urb. }\end{array}$ & Rau má & Lá, thân & $\begin{array}{l}\text { Ån, nước } \\
\text { giăi khât }\end{array}$ & Hái & Mùa hè \\
\hline 18 & $\begin{array}{l}\text { Chenopodium ficifolium } \\
\text { Sw. }\end{array}$ & Rau muối & Lá, thân & $\begin{array}{l}\text { Ăn, chăn } \\
\text { nuôi }\end{array}$ & Hái & $\begin{array}{l}\text { Mùa hè, } \\
\text { mùa thu }\end{array}$ \\
\hline 19 & $\begin{array}{l}\text { Meliantha suavis } \\
\text { Pierre. }\end{array}$ & Rau sắng & $\begin{array}{l}\text { Lá, chồi } \\
\text { non }\end{array}$ & Ăn, bán & Hái & Tháng 3-4 \\
\hline 20 & $\begin{array}{c}\text { Crassocephalum } \\
\text { crepididoides (Benth.) } \\
\text { S. Moore }\end{array}$ & $\begin{array}{c}\text { Rau tàu } \\
\text { bay }\end{array}$ & $\begin{array}{l}\text { Lá, ngọn } \\
\text { non }\end{array}$ & $\begin{array}{l}\text { Ăn, chăn } \\
\text { nuôi }\end{array}$ & Hái & Mùa hè \\
\hline 21 & $\begin{array}{c}\text { Dracontomelum } \\
\text { duperreanum Pierre. }\end{array}$ & Sấu & Quå & $\begin{array}{l}\text { Ån, nước } \\
\text { giải khát }\end{array}$ & Hái & Tháng 6-9 \\
\hline 22 & $\begin{array}{l}\text { Rhodomyrtus tomentosa } \\
\text { (Air.) Hassk. }\end{array}$ & Sim & Quả & 1, bán & Hái & Tháng 7-8 \\
\hline 23 & $\begin{array}{c}\text { Ficus racemosa } \mathrm{L} \text {. var. } \\
\text { miquelii }\end{array}$ & Sung & $\begin{array}{l}\text { Lá non, } \\
\text { quá }\end{array}$ & Ăn & Hái & $\begin{array}{l}\text { Cuối hè, đầu } \\
\text { thu }\end{array}$ \\
\hline 24 & G. cowa Roxb. & Tai chua & Quả & Ån, bán & Hái & Tháng 8-9 \\
\hline 25 & Cissampelos pareira $\mathrm{L}$. & Tiêt dê & Lá, thân & $\begin{array}{l}\text { Än, bán, } \\
\text { làm nước } \\
\text { giải khát }\end{array}$ & Hái & Quanh năm \\
\hline 26 & $\begin{array}{l}\text { Canarium tramdemum } \\
\text { Dai. \& Yakovl. }\end{array}$ & Trám đen & Quả & án & Hái & Tháng 8-10 \\
\hline 27 & $\begin{array}{l}\text { Canarium album } \\
\text { Raeusch. }\end{array}$ & $\begin{array}{l}\text { Trám } \\
\text { trắng }\end{array}$ & Quả & bán & Hái & Tháng 8-10 \\
\hline 28 & $\begin{array}{c}\text { Bambusa blumeana } \\
\text { Schunt. }\end{array}$ & Tre gai & Măng & Ān, bán & Đào & Tháng 8-11 \\
\hline 29 & $\begin{array}{c}\text { Bambusa nutans Wall. } \\
\text { ex Munro. }\end{array}$ & Vầu & Măng & Ăn, bán & Đào & Tháng 8-11 \\
\hline
\end{tabular}

(Nguồn: Số liệu điều tra của tác giả)

3.1.5. Hoạt động khai thác cây làm thức ăn cho gia súc

Hiện nay, chăn nuôi đại gia súc ở các xã thuộc Khu di tích nói riêng và hai huyện Sơn Dương, Yên Sơn nói chung đã và đang phát triển, mật độ gia súc chăn thả cao và phương thức chăn thả rông đã gây ảnh hưởng đến thảm thực vật rừng. Kết quả thống kê cho thấy, tổng số đàn gia súc của hai huyện Sơn Dương và Yên Sơn năm 2013 là 55.092 con, đến năm 2017 là 76.782 con, trong 5 năm đã tăng thêm 21.690 con [2]. Với quy mô và số lượng gia súc tăng đã ảnh hưởng không nhỏ đến thảm thực vật rừng.

Trong những năm gần đây, số lượng đàn gia súc (trâu, bò, dê...) của các hộ gia đình trong địa bàn Khu di tích tăng nhanh đã góp phần nâng cao thu nhập và cải thiện cuộc sống của người dân. Tuy nhiên, nguồn thức ăn tự nhiên không đáp ứng được nhu cầu do thiếu bãi chăn thả. Vì vậy, người dân phải khai thác một số loài cây mọc tự nhiên, nhất là trong các thảm thực vật rừng. Các loài cây làm thức ăn cho gia súc trong Khu di tích đã ghi nhận được 64 loài (chiếm 8,82\%). Tuy nhiên, các loài thường xuyên khai thác chủ yếu tập trung ở các họ Hòa thảo (Poaceae), họ Đậu (Fabaceae), họ Rau dền (Amaranthaceae) gồm: Cỏ lá tre (Centotheca lappacea), Cỏ mần trầu (Eleusine indica), Cỏ mồm timor (Ischaemum timorense), Cỏ lau (Saccharum arundinaceum), Đậu dại (Dunbaria podocarpa), Dền gai (Amaranthus spinosus)...; Từ thực trạng này chính quyền địa phương cần có giải pháp quy hoạch các bãi chăn thả để sử dụng lâu dài, đồng thời cần có kế hoạch hướng dẫn người dân trồng thêm cây thức ăn gia súc trong các vườn nhà, vườn rừng như Cỏ voi (Pennisetum purpureum) để đảm bảo đủ nguồn thức ăn, tránh làm suy giảm đa dạng loài thực vật. Các loài cụ thể được ghi ở Bảng 9.

Bảng 9. Các loài cây thưòng làm thức ăn cho gia súc tại Khu di tích lịch sủ Tân Trào

\begin{tabular}{|c|c|c|}
\hline \multirow{2}{*}{ TT } & \multicolumn{2}{|l|}{ Tên loài } \\
\hline & Tên Khoa học & Tên Việt Nam \\
\hline 1 & Eragrostis interrupta Beauv. & Cỏ bông \\
\hline 2 & Dactyloctenium aegypiacum (L.) Willd. & Cỏ chân vịt \\
\hline 3 & Cynodon dactylon (L) Rers & Cỏ gà \\
\hline 4 & Apluda varia var. mutica Hos. & Cỏ hoa tre \\
\hline 5 & Centotheca lappacea (L.) Desv. & Cỏ lá tre \\
\hline 6 & Saccharum arundinaceum Retz. & Cỏ lau \\
\hline 7 & Eleusine indica (L.) Gaertn. & Cỏ mần trầu \\
\hline 8 & Ischaemum timorense Kunth. & Có mồm timor \\
\hline 9 & Dunbaria podocarpa Kutz. & Đậu dại \\
\hline 10 & Amaranthus spinosus L. & Dền gai \\
\hline
\end{tabular}

(Nguồn: Số liệu điều tra của tác giả)

\subsubsection{Hoạt động khai thác cây làm cảnh}

Khu vực nghiên cứu ghi nhận được 99 loài (chiếm $9.20 \%$ tổng số loài thực vật). Bảng 9 là danh sách các loài cây làm cảnh người dân thường khai thác. Một số đại diện như: Đuôi chồn (Adiantum caudatum), Sơn tuế (Cycas balansae), Si sanh (Ficus benjamina), Kim tán (Calanthe angusta), Trúc vuông (Chimonobambusa quadrangulais)...

Bảng 10. Danh sách các loài cây khai thác làm cảnh tại Khu di tích lịch sủ Tân Trào

\begin{tabular}{|c|l|c|}
\hline \multirow{2}{*}{ TT } & \multicolumn{2}{|c|}{ Tên loài } \\
\cline { 2 - 3 } & \multicolumn{1}{|c|}{ Tên khoa học } & Tên Việt Nam \\
\hline 1 & Adiantum caudatum L. & Đuôi chồn \\
\hline 2 & Dracaena cochinchinensis (Lour.) S.C.Chen & Huyết giác \\
\hline 3 & Calanthe angusta Lindl. & Kim tán \\
\hline 4 & Baringtonia asiatica (L.) Kurz & Lộc vừng \\
\hline 5 & Pothos repens (Lour.) Druce. & Ráy leo \\
\hline 6 & Streblus asper Lour. & Ruối \\
\hline 7 & Ficus benjamina L. & Si sanh \\
\hline 8 & Cycas balansae Warb. & Sơn tuế \\
\hline 9 & Paphiopedilum hirsutissimum Stein. & Tiên hài \\
\hline 10 & Chimonobambusa quadrangulais (Fenzi) Makino & Trúc vuông \\
\hline
\end{tabular}

(Nguồn: Số liệu điều tra của tác giả)

Trong những năm gần đây số lượng người chơi cây cảnh nói chung và chơi hoa Lan ngày càng đông, nhiều người săn tìm các loài lan quý hiếm như Tiên hài (Paphiopedilum hirsutissimum), Hài tía ( $P$. 
purpuratum)..., chúng chỉ còn ở những địa hình hiểm trở trên các núi đá hoặc các cây cao trong rừng sâu. Qua điều tra chúng tôi nhận thấy trước đây người dân chỉ quan tâm đến các loài cây làm thuốc thì ngày nay họ quan tâm hơn đến các loài cây làm cảnh, vì những loài này mang lại lợi nhuận cao. Do đó, việc người dân vào rừng tìm kiếm và khai thác các loài lan đã gây ảnh hưởng rất lớn đến thảm thực vật rừng nói chung và suy giảm các loài Lan nói riêng, một số loài có nguy cơ cạn kiệt.

\subsection{Anh hương của con người đến thành phần và cấu trúc thảm thỵc vật}

Do sự tác động trong thời gian dài trước đây của con người đến thành phần loài, cấu trúc phân tầng của rừng tự nhiên mà hiện nay ở khu di tích có nhiều kiểu thảm thực vật khác nhau. Các kiểu thảm thực vật này có sự khác nhau rõ rệt giữa rừng tự nhiên được bảo vệ và rừng tái sinh bị khai thác kiệt.

3.2.1. Thành phần loài và cấu trúc của rùng tụ nhiên trong khu vục it bị tác động

Đại diện đặc trưng là phân quần hệ Rừng kín lá rộng thường xanh ở địa hình thấp và núi thấp bị tác động nhẹ. Kiểu phụ rừng này gặp ở một số xã của khu di tích như Tân Trào, Lương Thiện..., nơi xa khu dân cư, ở độ cao từ 300-700m so với mực nước biển, phân bố chủ yếu trên núi đất, một số ít ở núi đá vôi. Mặc dù đã bị khai thác một số loài cây gỗ quý, nhưng cơ bản kiểu rừng này vẫn giữ được tính chất nguyên sinh vốn đã từng tồn tại ở khu vực trước đây. Cấu trúc của rừng có 5 tầng, trong đó có 3 tầng cây gỗ rõ rệt:

Tầng vượt tán $(\mathrm{A} 1)$ có chiều cao trung bình 25 $30 \mathrm{~m}$, đường kính trung bình $35-40 \mathrm{~cm}$, có tán không đều và độ che phủ 20 - 25\%. Tầng này gồm các loài như: Hoàng linh bắc bộ (Peltophorum dasyrrhachis), Chò nâu (Dipterocarpus retusus), Chò chỉ (Parashorea chinensis), Đinh (Markhamia stipulata), Trám trắng (Canarium album), Trám đen (Canarium tramdenum), Táu muối (Vatica diospyroides), Mý (Lysidice rhodostegia), Trai lý (Garcinia fragraeoides), Xoan nhừ (Allospondias axilaris), các loài thuộc chi Castanopsis, chi Lithocarpus của họ Dẻ (Fagaceae)...

Tầng tán rừng $(\mathrm{A} 2)$ có rất nhiều loài tham gia tạo thành một tầng tán khá liên tục, chiều cao trung bình 15 - 20m, đường kính đạt $20-30 \mathrm{~cm}$ và độ che phủ 50 $60 \%$. Thành phần thực vật gồm các loài như: Gội (Aglaia dasyclada), Dẻ gai (Castanopsis armata), Trám trắng (Canarium album), Giổi lông (Michelia balansae), Kháo vàng (Machilus bonii), Dẻ phú thọ
(Castanopsis phuthoensis), Chẹo tía (Engelhardtia roburghiana)...

Tầng dưới tán (A3) chủ yếu là các loài cây gỗ có chiều cao $7-10 \mathrm{~m}$, đường kính đạt từ $15-20 \mathrm{~cm}$ và độ che phủ đạt $30 \%$. Các đại diện của tầng này gồm: Cà ồi (Castanopsis tesselata), Sấu (Dracontomelon dupereanum), Chẹo tía (Engelhardtia roburghiana), Đu đủ rừng (Trevesia palmata), Nhãn rừng (Nephelium cuspidatum), Sảng (Sterculia lanceolata), Ràng ràng (Ormosia balanse)...

Tầng cây bụi $(\mathrm{B})$ có thành phần thực vật chủ yếu là các loài thuộc họ Đơn nem (Myrsinaceae), họ Mua (Melastomataceae), họ Cam quýt (Rutaceae), họ Na (Anononaceae)...

Tầng thảm tươi $(\mathrm{C})$ là các loài thuộc họ Hoà thảo (Poaceae), họ Ráy (Araceae), họ Gừng (Zingiberaceae), họ Thông đất (Lycopodiaceae)... Độ che phủ từ 20$30 \%$.

Thực vật ngoại tầng gồm các loài dây leo khá phong phú như Gắm núi (Gnetum montanum), Hoa Giẻ (Desmos chinensis), Dây hương (Erythropalum scandens), Mây (Calamus tonkinensis)...Các loài thực vật bì sinh tiêu biểu như Cốt toái bổ (Drynaria fortunei), Tắc kè đá (Drynaria bonii), Quyết tổ diều (Asplenium nidus), Đuôi phượng (Rhaphidophora decursiva)...

3.2.2. Thành phần loài và cấu trúc của rùng tụ nhiên trong khu vực bị khai thác kiệt

Đại diện đặc trưng là phân quần hệ Rừng tre nứa nhiệt đới ở địa hình thấp và núi thấp. Kết quả điều tra cho thấy rừng tre nứa đều có nguồn gốc phát sinh hình thành từ rừng kín thường xanh mưa mùa nhiệt đới ở địa hình thấp và núi thấp do khai thác quá mức hoặc chặt đốt rừng làm nương rẫy. Trong loại rừng này tùy theo mức độ tham gia của cây gỗ lá rộng mà hình thành nên rừng thuần loài hay hỗn giao.

- Rùng thuần loài: Đặc trưng bởi loại hình rừng Nứa (Neohouzeana dulloa) hình thành sau khai thác kiệt hoặc đốt rừng làm nương rẫy, phân bố ở độ cao dưới $400 \mathrm{~m}$. Kiểu này có diện tích khá lớn, tạo thành tầng tán rừng với ưu thế là Nứa có chiều cao $6-8 \mathrm{~m}$, đường kính trung bình $3-5 \mathrm{~cm}$, độ che phủ $80-90 \%$. Dưới tán rừng Nứa chỉ gặp một số ít loài thực vật như Trung quân (Ancistrocladus scandens), Mây (Calamus tonkinensis), Mía dò (Costus speciosus), Chặc chìu (Tetracera scandens)..., gặp nhiều ở các xã Hùng Lợi, Trung Minh, Kim Quan, Trung Yên, Tân Trào... 
- Rùng hôn giao vói cây lá rộng: Trong loại rừng này, ngoài tầng chính của rừng ưu thế bởi loài Nứa cao $6-8 \mathrm{~m}$, rừng có 1 tầng cây gỗ cao $15-20 \mathrm{~m}$, độ tàn che 0,2 - 0,3. Một số loài cây gỗ như Gội đỏ (Aglaia dasyclada), Chẹo tía (Engelhardtia roburghiana), Kháo (Machilus bonii), Kháo nhớt (Phoebe tavoyana), Ràng ràng (Ormosia balansae), Mý (Lysidice rhodostegia), Dẻ gai (Castanopsis indica), Côm (Elaeocarpus angustifolius), Thôi ba (Alangium chinense), Nóng nâu (Saurauja nepalensis)...; Tầng cây bụi và thảm tươi có thành phần loài cây chịu bóng nhiều hơn so với rừng Nứa thuần loài. Loại rừng hỗn giao có ở tất cả các xã trong khu di tích.

Mặt khác, các hoạt động tích cực của con người như khoanh nuôi, xúc tiến tái sinh phục hồi tự nhiên, hay trồng rừng..., đã làm phong phú thêm thành phần loài của hệ thực vật.

\section{Kết luận}

Kết quả nghiên cứu tại Khu di tích lịch sử Tân Trào, tỉnh Tuyên Quang đã cho thấy: Thành phần loài và cấu trúc của rừng tự nhiên trong khu vực ít bị tác động, cấu trúc của rừng có 5 tầng, trong đó có 3 tầng cây gỗ rõ rệt: Tầng vượt tán (A1), tầng tán rừng (A2), tầng dưới tán $(\mathrm{A} 3)$; tầng cây bụi $(\mathrm{B})$; tầng thảm tươi (C). Rừng tre nứa đều có nguồn gốc phát sinh hình thành từ rừng kín thường xanh mưa mùa nhiệt đới ở địa hình thấp và núi thấp: Rừng thuần loài gặp nhiều ở các xã Hùng Lợi, Trung Minh, Kim Quan, Trung Yên, Tân Trào; Rừng hỗn giao với cây lá rộng có ở tất cả các xã trong khu di tích.

Qua điều tra cho thấy những hoạt động khai thác quá mức nguồn tài nguyên rừng ở đây đã làm suy giảm mạnh tính đa dạng của các nhóm loài thực vật rừng. Những hoạt động khai thác quá mức của con người không những làm suy giảm thành phần loài cây gỗ lớn và các loài cây có giá trị làm thuốc, làm cảnh, làm thức ăn gia súc,... mà còn làm cho cấu trúc của rừng bị phá vỡ, do đó làm giảm khả năng phòng hộ bảo vệ môi trường của rừng cũng như chức năng tạo nên cảnh quan cho Khu di tích. Các ban ngành chức năng cần sớm có các biện pháp để duy trì, bảo vệ và phát triển rừng.

\section{TÀI LIỆU THAM KHẢO}

1. Ban Quản lý Khu di tích (2013), Hồ sơ quy hoạch tổng thể bảo quản, tu bổ, phục hồi, và phát huy giá trị di tích Quốc gia đặc biệt Tân Trào tỉnh Tuyên Quang gắn với phát triển du lịch đến năm 2025, tỉnh Tuyên Quang.

2. Brummitt RK (1992), Vascular plant families and genera, Royal Botanic Gardens, Kew.

3. Chính phủ nước Cộng hoà xã hội chủ nghĩa Việt Nam, Quyết định số 2543/QĐ-TTg, ngày 20 tháng 12 năm 2013 của Thủ tướng Chính phủ về việc phê duyệt nhiệm vụ Quy hoạch tổng thể bảo quản, tu bổ, phục hồi và phát huy giá trị di tích lịch sử quốc gia đặc biệt Tân Trào, tỉnh Tuyên Quang gắn với phát triển du lịch đến năm 2025, Hà Nội, 2013.

4. Cục thống kê tỉnh Tuyên Quang, Niên giám thống kê tỉnh Tuyên Quang, năm 2016, 2017.

5. Hoàng Chung (2008), Các phương pháp nghiên cứu quần xã thưcc vật, Nxb Giáo dục, Hà Nội

6. Nguyễn Nghĩa Thìn (2007), Các phưong pháp nghiên cứu thực vật, Nxb Đại học Quốc gia, Hà Nội.

7. Nguyễn Tiến Bân (chủ biên) (2003, 2005), Danh luc các loài thực vật Việt Nam (tập 2, tập 3), Nxb Nông nghiệp, Hà Nội.

8. Phạm Hoàng Hộ (1999, 2003, 2000), Cây cỏ Việt Nam (quyển I, II, III), Nxb Trẻ, Tp HCM.

9. Raunkiaer C., Plant life forms, Claredon, Oxford, 1934.

10. Trần Đình Lý (1993), 1900 loài cây có ich ở Việt Nam, Nxb Thế giới.

11. Triệu Văn Hùng (chủ biên) (2007), Lâm sản ngoài gố ở Việt Nam, Nxb Bản đồ, Hà Nội.

12. Võ Văn Chi (2012), Tù điển cây thuốc Việt Nam (tập 1, 2), Nxb. Y học, Hà Nội. 


\section{Studying about human influence of plant diversity at Tan Trao historical relic, Tuyen Quang province}

\section{Do Cong Ba}

\section{Article info}

Recieved:

$10 / 01 / 2020$

Accepted:

$10 / 3 / 2020$

Keywords:

Relics; exploitation;

Diversity; Tan Trao;

Tuyen Quang province.

\begin{abstract}
Studying results at Tan Trao historical relic, Tuyen Quang province showed that excessive exploitation of forest resources here reduced strongly the diversity for plant species in forest. Group of medicinal plants has 470 species, in which 10 species are exploited with a high frequency including Morinda officinalis, Stephania dielsiana, Multiflora Fallopia, Ardisia silvestris, Drynaria fortunei....; The group of edible plants has 142 species that are also regularly collected and eradicated such as Melientha suavis, Diplazium esculentum, Canarium tramdenum, Canarium album, bamboo shoots such as Bambusa nutans, Neohouzeaua, Ampelocalamus; The group of ornamental plants have 99 species including Barringtonia acutangula, Banyan, Ficus benjamina and Chimonobambusa quadrangularis...; The group of plants extracted for oil which has 69 species, accounting for 9,5\% of total number of species surveyed in the studying area. Some common species are Desmos pedunculosus, Xanthiuminae quilaterum, Litsea cubeba, Sapindus saponaria, etc. Due to long-term impact caused by human on species, the stratified structure of natural forest, there are many different types of vegetation in the relic which differ significantly between protected natural forests and exhaustedly-exploited regenerated forests.
\end{abstract}

